\title{
CHANGES IN BODY FLUID AND ENERGY COMPARTMENTS DURING PROLONGED HUNGER STRIKE
}

Joel Faintuch, Francisco Garcia Soriano, José Paulo Ladeira, Mariano Janiszewski, Irineu Tadeu Velasco and Joaquim J. Gama-Rodrigues

RHCFAP/3002

FAINTUCH J et al. - Changes in body fluid and energy compartments during prolonged hunger strike. Rev. Hosp. Clín. Fac. Med. S. Paulo 55 (2):47-54, 2000.

SUMMARY: Prolonged total food deprivation in non-obese adults is rare, and few studies have documented body composition changes in this setting. In a group of eight hunger strikers who refused alimentation for 43 days, water and energy compartments were estimated, aiming to assess the impact of progressive starvation. Measurements included body mass index (BMI), triceps skinfold (TSF), arm muscle circumference (AMC), and bioimpedance (BIA) determinations of water, fat, lean body mass (LBM), and total resistance. Indirect calorimetry was also performed in one occasion. The age of the group was $43.3 \pm 6.2$ years (seven males, one female). Only water, intermittent vitamins and electrolytes were ingested, and average weight loss reached $17.9 \%$. On the last two days of the fast $\left(43^{\text {rd }}-44^{\text {th }}\right.$ day) rapid intravenous fluid, electrolyte, and vitamin replenishment were provided before proceeding with realimentation. Body fat decreased approximately $60 \%$ (BIA and TSF), whereas BMI reduced only $18 \%$. Initial fat was estimated by BIA as $52.2 \pm 5.4 \%$ of body weight, and even on the 43 rd day it was still measured as $19.7 \pm 3.8 \%$ of weight. TSF findings were much lower and commensurate with other anthropometric results. Water was comparatively low with high total resistance, and these findings rapidly reversed upon the intravenous rapid hydration. At the end of the starvation period, BMI $\left(21.5 \pm 2.6 \mathrm{~kg} / \mathrm{m}^{2}\right)$ and most anthropometric determinations were still acceptable, suggesting efficient energy and muscle conservation. Conclusions: 1) All compartments diminished during fasting, but body fat was by far the most affected; 2) Total water was low and total body resistance comparatively elevated, but these findings rapidly reversed upon rehydration; 3) Exaggerated fat percentage estimates from BIA tests and simultaneous increase in lean body mass estimates suggested that this method was inappropriate for assessing energy compartments in the studied population; 4) Patients were not morphologically malnourished after 43 days of fasting; however, the prognostic impact of other impairments was not considered in this analysis.

DESCRIPTORS: Hunger strike. Acute starvation. Prolonged fasting. Body composition. Nutritional assessment. Bioimpedance analysis.

Body composition changes during long-term hunger strike have not been reported frequently, and no study with bioimpedance analysis in this setting was found in the literature, because this is an uncommon and rarely documented clinical event. Much more is known about food deprivation in experimental animals ${ }^{5}$, or in other human nutritional deficiency states ${ }^{13}$, including therapeutic starvation for morbid obe- sity $^{6,20}$. However, it is debatable whether such findings should directly apply to long-term hunger strikers ${ }^{7,14}$, for the following reasons: 1) hunger strikes are typically undertaken by comparatively healthy adults with nor-

From the Department of Emergency Medicine and Nutrition Group, Hospital das Clínicas, Faculty of Medicine, University of São Paulo. mal body composition, but of variable ages; 2) unlike certain forms of spontaneous or therapeutic fasting, food suppression is usually complete and prolonged during hunger strikes; 3 ) the social and psychological context in most instances of hunger strike is not conducive to adequate clinical or morphological investigation of these subjects, rendering it difficult to establish disease patterns. It has been observed 
that mortality can be very high, especially as food deprivation reaches or exceeds about two months ${ }^{14}$.

In the present retrospective study, the results of bioimpedance analysis (BIA) and anthropometric estimations of body composition changes in a group of hunger strikers are reported, with the aim of evaluating the possible contributions of these methods towards a better understanding of the metabolic consequences of long-term total food deprivation.

\section{PATIENTS AND METHODS}

The population consisted of eight prisoners serving long sentences who engaged in a difficult legal dispute with government authorities, and within that context started a hunger strike. During the first 11 days they remained within the correctional facility, but afterwards seven of them were transferred to the hospital for clinical observation (the eighth case arrived one week later).

The hospital was requested to do whatever necessary to keep the prisoners alive, but there obviously were technical, psychological, and legal constraints. For ethical reasons it was decided that, except during emergencies, all diagnostic or therapeutic procedures would be submitted to the prisoners for specific previous approval. As a consequence, no investigation protocol or standardized therapeutic approach could be formulated, not only because of the sensitivities and anxieties of the population, but also because it was not possible to forecast the duration of the fasting.

For similar ethical and legal reasons, realimentation would only be attempted by force if the situation of the patients became critical. Fortunately, by the time it was suspected that their clinical conditions were starting to deteriorate and intravenous fluids were introduced, their problems with the au- thorities were adequately solved, and medical advice regarding food intake was therefore spontaneously accepted.

The total hunger strike extended for 46 days, but by the $43^{\text {rd }}$ day, a large intake of intravenous fluids and electrolytes was provided to offset hydro-electrolytic and vitamin imbalance. From the $43^{\text {rd }}$ day until the 46th day, modest amounts of hypocaloric parenteral feeding (mean daily intake of 535 \pm $206 \mathrm{kcal}$ and $10.3 \pm 2.5 \mathrm{~g}$ of amino acids) were supplied to these individuals. Otherwise only water was accepted during the first six weeks, with occasional vitamins and electrolytes to correct clinical manifestations or biochemical imbalances. The current investigations address the first 43 days of this period.

The age of the population was $43.3 \pm 6.2$ years $(33-52)$, and there were seven males and one female. Initial body mass index (BMI) was $26.1 \pm 2.7 \mathrm{~kg} / \mathrm{m}^{2}(20.8-30.1)$, and no relevant medical or surgical disease was identified in the clinical history, except for essential arterial hypertension in one male case and urinary infection in the female patient. There was no mortality in this series, and after adequate realimentation, all subjects were discharged in good condition.

Anthropometric determinations included body weight and height, BMI, arm circumference, triceps skinfold (TSF), and arm muscle circumference (AMC). For the last two variables, the adopted normal references were respectively $12.5 \mathrm{~mm}$ and $25.3 \mathrm{~cm}$ for males, and $16.5 \mathrm{~mm}$ and $23.2 \mathrm{~cm}$ for females ${ }^{2}$.

Bioimpedance analysis (BIA) was done on a few occasions. The standard tetrapolar technique employing a single current apparatus $(50 \mathrm{kHz})$ was used (Biodynamics model 310, Biodynamics, Seattle, Washington, USA). The following variables were documented: body fat, lean body mass (LBM), total body water, resistance, and reactance.
Both absolute values and \% of body weight were examined.

Basal energy expenditure (BEE) was calculated according to the Harris Benedict equation (HBE). Whenever corrections or adjustments were introduced, the corresponding citation is indicated. The opportunity to perform indirect calorimetry occurred only once when a 33-year-old male on the $17^{\text {th }}$ day of food deprivation agreed to the test. The apparatus was a Deltatrac MB-101, Sensormedics, Yorba Linda, CA, USA, and the measurement was done by a trained technician. Steady state was defined as a 30-minute period during which the coefficient of variation of oxygen consumption and $\mathrm{CO}_{2}$ production was equal or below $10 \%$.

Statistical analysis: Values are presented as mean \pm SEM or as percentage. For selected variables, linear regression analysis was performed to estimate missing values in the beginning or end of the observation period. In such circumstances, the correlation index $(r)$ and the $(\mathrm{p})$ value are indicated. Comparison between initial and final results within the group was done by twotailed Student's $t$ test. A significance level of 5\% was adopted.

This study was approved by the Ethical Committee of Hospital das Clinicas and São Paulo University Medical School.

\section{RESULTS}

Patients were initially well-nourished but lost nearly $18 \%$ of their body weight. Reduction for TSF was substantial (from $158.5 \%$ to $63.8 \%$ of normal, or $94.7 \%$ decrease), however AMC was affected by only $15.1 \%$. These results as well as the calculated BEE for various time periods can be seen in Table 1.

Bioimpedance analysis was documented on two occasions during the period of total fast, and the respective 
Table 1 - Anthropometric findings.

\begin{tabular}{lccllll}
\hline & $\begin{array}{c}\text { Weight } \\
(\mathrm{Kg})\end{array}$ & $\begin{array}{c}\text { Weight loss } \\
(\%)\end{array}$ & $\begin{array}{c}\text { BMI } \\
\left(\mathrm{Kg} / \mathrm{m}^{2}\right)\end{array}$ & $\begin{array}{c}\text { TSF } \\
(\mathrm{mm})\end{array}$ & $\begin{array}{c}\text { AMC } \\
(\mathrm{cm}\end{array}$ & $\begin{array}{c}\text { BEE } \\
(\mathrm{Kcal} / \text { day })\end{array}$ \\
\hline Admission $^{* *}$ & $80.9 \pm 8.2$ & 0 & $26.1 \pm 2.7$ & & & $1742 \pm 186$ \\
11th day & $72.1 \pm 6.8^{*}$ & $8.9 \pm 2.7$ & $23.3 \pm 2.5^{*}$ & $17.8 \pm 2.8$ & $24.4 \pm 1.0$ & $1623 \pm 169^{*}$ \\
18th day & $69.0 \pm 6.6^{*}$ & $14.8 \pm 3.1$ & $22.3 \pm 2.3^{*}$ & $15.5 \pm 3.5^{*}$ & $22.9 \pm 1.4^{*}$ & $1591 \pm 137^{*}$ \\
31st day & $66.3 \pm 5.8^{*}$ & $17.9 \pm 2.0$ & $21.4 \pm 2.2^{*}$ & $11.9 \pm 2.2^{*}$ & $22.5 \pm 1.5$ & $1545 \pm 146$ \\
43rd day** & $66.4 \pm 6.6$ & $17.6 \pm 2.4$ & $21.5 \pm 2.6$ & & & $1550 \pm 151$ \\
\hline
\end{tabular}

$\mathrm{BMI}=$ inicial body mass index

$\mathrm{TSF}=$ triceps skinfold

$\mathrm{AMC}=$ mid arm circumference $-0,314 \times \mathrm{TSF}$

$\mathrm{BEE}=$ Harris-Benedict equation

$* \mathrm{p}<0.05$ (in comparison with previous values)

**TSF and AMC not available due to technical problems. Estimated average values for TSF (linear regression analysis, $r=-0.9985$,

$\mathrm{p}=0.035)$ :Admission 20.6 (158.5\% of normal) and 43rd day 8.3 (63.8\% of normal)

For AMC ( $r=-0.8423, \mathrm{p}=0.362)$ : Admission 25.0 (99.8\% of normal) and 43rd day 21.2 (84.7\% of normal)

findings are displayed in Table 2. Body fat on the 31 st day of starvation was $26.8 \%$ of body weight. Projecting the rate of daily change to the first day, an unusual proportion of $52.2 \%$ of body weight as adipose tissue resulted. Total water remained within the low-normal range on the first date of registration, markedly increasing 12 days later, along with the corresponding reduction in resistance.

BEE was routinely obtained from the Harris-Benedict equation (HBE), but the bioimpedance apparatus furnishes its own estimate of that equation, which was also taken into account. Because of possible interference of progressive starvation on traditional findings of BEE , as described by several authors ${ }^{7,14}$, BEE data was mathematically manipulated to assess the probable impact on fuel oxidation and severity of tissue loss, or total energy expenditure. As demonstrated in Table 3, discrepancies concerning BEE were relatively minor; however, much greater differences were unveiled during the estimation of total energy expenditure (TEE).

Indirect calorimetry could not be serially employed due to technical and psychological barriers. It was successfully measured only once (Table 4). The respiratory quotient was extremely low (0.68), and energy expenditure also remained $13 \%$ below the HBE cal-
Table 2 - Principal bioimpedance results.

\begin{tabular}{cccccc}
\hline $\begin{array}{l}\text { Fat } \\
(\%)\end{array}$ & $\begin{array}{c}\text { Fat weight } \\
(\mathrm{Kg})\end{array}$ & $\begin{array}{l}\mathrm{H}_{2} \mathrm{O} \\
(\%)\end{array}$ & $\begin{array}{c}\mathrm{H}_{2} \mathrm{O} \text { volume } \\
(\mathrm{L})\end{array}$ & $\begin{array}{c}\text { Resistance } \\
(\mathrm{Ohm})\end{array}$ \\
\hline 31st day & $26.8 \pm 6.2 \%$ & $17.6 \pm 3.9$ & $52.1 \pm 3.7 \%$ & $35.1 \pm 4.5$ & $639 \pm 80$ \\
43rd day & $19.7 \pm 3.8 \%$ & $12.9 \pm 1.8^{*}$ & $57.8 \pm 3.2 \%$ & $38.4 \pm 5.2 *$ & $550 \pm 78^{*}$ \\
\hline
\end{tabular}

$* \mathrm{p}<0.05$ (in comparison with initial values)

Table 3 - Estimated basal energy expenditure BEE and total energy expenditure TEE during period of hunger strike.

\begin{tabular}{lccccc}
\hline & Harris-Benedict BEE & Apparatus BEE & Adjusted BEE & TEE** & TEE $^{* * *}$ \\
\hline Admission & $1742 \pm 186$ & & 2021 & & \\
31st day & $1545 \pm 146^{*}$ & $1480 \pm 203$ & $1483 \pm 80$ & $1414^{*}$ & 1244 \\
43rd day & $1550 \pm 151$ & $1626 \pm 220^{*}$ & $1515 \pm 81$ & 1414 & 1240 \\
\hline
\end{tabular}

$\mathrm{BEE}$ and $\mathrm{TEE}=\mathrm{Kcal} / \mathrm{day}$

Apparatus BEE $=$ Supplied by Biodynamics-BIA model 310

Adjusted BEE $=$ Dulloo \& Jacquet, $1998^{7}($ BMR kJ $=3482+52.9$ FFM kg +9.7 Fat kg),converted

to $\mathrm{Kcal} / \mathrm{day}$

${ }^{*} \mathrm{p}<0.05$ (in comparison with previous values)

**Leiter \& Marliss, $1982^{14}$ (Initial BEE = Harris-Benedict X 1.16; After three weeks: $30 \%$

decrease)

***Dulloo \& Jacquet, $1998^{7}$ (Thermogenic economy in moderate starvation:20\% below expected

$\mathrm{BEE})$,calculated from Harris- Benedict results

Table 4 - Indirect calorimetry results on the 18th day (33-year-old male, 1.73m, $69.3 \mathrm{~kg}$ ).

$\begin{array}{lc}\mathrm{VO}_{2}\left(\mathrm{ml} / \mathrm{min} / \mathrm{m}^{2}\right) & 217 \\ \mathrm{VCO}_{2}\left(\mathrm{ml} / \mathrm{min} / \mathrm{m}^{2}\right) & 146 \\ \mathrm{EE}(\mathrm{kcal} / \mathrm{day}) & 1440 \\ \mathrm{RQ} & 0.68 \\ \mathrm{BEE}(\mathrm{kcal} / \text { day }) & 1655 \\ \mathrm{EE} / \mathrm{BEE} & 0.87\end{array}$

$\mathrm{EE}=$ Energy expenditure

$\mathrm{RQ}=$ Respiratory quotient

$\mathrm{BEE}=$ Harris Benedict 
culation. This case, as well as all others, had positive urine tests for ketone bodies, not only during the time of the test, but during the entire hunger-strike period inside the hospital.

Spent calories for the complete analyzed period were computed using the straight Harris-Benedict equation, extrapolations based on the BIA readings, and modified HBE results as reported by several groups ${ }^{14,18}$. Forecasts of 59772 - 70211 burned kcal were obtained. The conversion of such expenditures into actual destruction of fat and non-fat mass produced theoretical contributions of $5957-7225 \mathrm{~g}$ of lipid reserves and $1046-1808 \mathrm{~g}$ of protein and carbohydrate (Table 5).
A similar calculation for probable total energy consumption can be followe in Table 6, but derived from measured tissue losses and their caloric equivalent.Different assumptions were adopted $^{8,14}$,as appropriate for serial measurements of body weight as well as of total fat (estimated by three methods).The deducted range of total kcal loss fluctuated widely, from 62311 up to 151704 for the studied period.

\section{DISCUSSION}

Uncomplicated starvation differs from traumatic and septic malnutrition in many aspects; one of these is the contribution of fat toward energy production. In prolonged hunger, fat is definitely the most consumed fuel, representing at least $90 \%$ of the total expenditure ${ }^{7,11,18}$. Its exhaustion may have implications for survival ${ }^{5,6,14,20}$ not unlike nitrogen $(\mathrm{N})$ loss. In undernourished critical patients, $\mathrm{N}$ excretion tends to be overwhelming, obfuscating the numerically superior but clinically less worrisome oxidation of fatty acids, and is therefore considered the limiting nutrient category.

In trauma, nitrogen balances in the range of $-8 \mathrm{~g} \mathrm{~N} /$ day are common ${ }^{9}$, and burn victims exhibit as much as 20 $25 \mathrm{~g}$ of $\mathrm{N}$ depletion in some phases of their hospitalization ${ }^{17}$. Such damage

Table 5 - Estimated total energy expenditure during 43 days of fasting, as furnished by BIA apparatus and Harris Benedict equation, and its equivalent in lost body mass (fat and protein oxidation) according to different methods of calculation (Same references as Table 3$)^{*}$.

\begin{tabular}{|c|c|c|c|c|c|}
\hline & Harris-Benedict & Apparatus & Dulloo\&Jacquet $^{7}$ & Adj.Dulloo\&Jacquet ${ }^{7}$ & Leiter\&Marliss $^{14}$ \\
\hline $0-31$ st day & 51119 & 49941 & 49987 & 45384 & 53243 \\
\hline 31 - 43rd day & 18636 & 18636 & 17988 & 14388 & 16968 \\
\hline Sum total & 69755 & 68577 & 67975 & 59772 & 70211 \\
\hline Weight equiv.** & $\begin{array}{l}1796+6952 \\
(8748)\end{array}$ & $\begin{array}{l}1766+6835 \\
(8601)\end{array}$ & $\begin{array}{l}1750+6775 \\
(8525)\end{array}$ & $\begin{array}{l}1539+5957 \\
(7496)\end{array}$ & $\begin{array}{l}1808+6998 \\
(8806)\end{array}$ \\
\hline Weight equiv. ${ }^{* * *}$ & $\begin{array}{l}1221+7208 \\
(8429)\end{array}$ & $\begin{array}{l}1200+7086 \\
(8286)\end{array}$ & $\begin{array}{l}1190+7024 \\
(8214)\end{array}$ & $\begin{array}{l}1046+6176 \\
(7222)\end{array}$ & $\begin{array}{l}1229+7225 \\
(8484)\end{array}$ \\
\hline
\end{tabular}

*Daily energy expenditure calculated as mean between initial and final values for the period; Initial energy expenditure always based on HarrisBenedict equation except when the apparatus measurements are mentioned ;Energy in kcal, weight in g; caloric value of fat: $9 \mathrm{kcal} / \mathrm{g}$; caloric value of carbohydrate or protein: $4 \mathrm{kcal} / \mathrm{g}$

**Leiter \& Marliss, $1982^{14}$ : $10.3 \%$ of calories supplied by protein+carbohydrate, remainder by fat

$* * *$ Owen et al, $1998^{18}$ : $7.0 \%$ of calories furnished by protein+carbohydrate,remainder by fat

${ }^{\mathrm{f}}$ Average weight loss for the studied patients during the analyzed period, including fluids and electrolytes (Initial weight, $80.9 \pm 8.2 \mathrm{~kg}$, weight on $43 \mathrm{rd}$ day, $66.4 \pm 6.6 \mathrm{~kg})$

Table 6 - Energy expenditure estimated from measured loss of body weight and body fat.

\begin{tabular}{lccc}
\hline & Body weight & Body fat TSF & Body fat* \\
\hline Projected initial body fat & $337 \mathrm{~g}$ & $30.6 \%(24.8 \mathrm{~kg})$ & $37.0 \%(29.9 \mathrm{~kg})$ \\
Average consumption/day & $4.3 \mathrm{kcal} / \mathrm{g}^{\mathrm{ff}}$ & $345 \mathrm{~g}$ & $250 \mathrm{~g}$ \\
Conversion factor & 62311 & $9 \mathrm{kcal} / \mathrm{g}$ & $92.2 \%(42.2 \mathrm{~kg})$ \\
Total kcal loss (43 days) & 133515 & $9 \mathrm{kcal} / \mathrm{g}$ & 96750 \\
\hline
\end{tabular}

$\mathrm{TSF}=$ Initial triceps skinfold estimated as $158.5 \%$ of normal (linear regression analysis, $\mathrm{r}=-0.99, \mathrm{p}=0.035$ ); ideal body fat deducted from Heitmann equation ${ }^{10}(\%$ Fat $=0.988 \mathrm{BMI}+0.242 \mathrm{Wt}+0.094 \mathrm{~A}-30.18=19.3 \%$ body weight $)$, and corrected for the measured excess adiposity, to $30.6 \%$

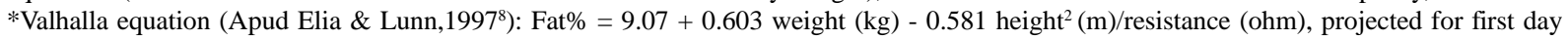

***Bodynamics model 310

${ }^{\mathrm{f}}$ Considering first and 43rd day findings

${ }^{\mathrm{ff}}$ Mean corresponding energy value indicated by Leiter \& Marliss, $1982^{14}$ 
compounds the prevailing tendency towards body mass erosion, even when food intake is present. Before the modern era of clinical nutrition, adults suffering from burns exceeding $40 \%$ of body surface lost $22 \%$ of body weight within two months, even though they were receiving standard complete hospital diets ${ }^{17}$.

In the hypothetical situation of a healthy $70-\mathrm{kg}$ adult male with $13 \mathrm{~kg}$ of body protein (2080 $\mathrm{g}$ of nitrogen) and $160000 \mathrm{kcal}$ of fat $(17.8 \mathrm{~kg})^{2}$, who experiences a loss of $60 \mathrm{~g}$ of protein $(9.6$ $\mathrm{g} \mathrm{N}$ ) and $150 \mathrm{~g}$ of fat per day ${ }^{19}$, protein would be exhausted in 217 days and adipose tissue in 119 days. Given the fact that in acute conditions, survival is unlikely when more than one third of body protein is degraded ${ }^{13}$, available life span would not exceed 72 days. If a negative nitrogen balance of $-20 \mathrm{~g} /$ day is assumed, for instance because of trauma or sepsis, then that theoretical deadline would recede to only 35 days. As emphasized previously, the limiting substrate is more often protein, but fat deficit may become critical in circumstances of uncomplicated but prolonged starvation, when massive consumption of body fat stores are prone to occur ${ }^{4,14}$.

Hunger strike is not counted among the metabolically stressful conditions, and catabolism is subdued in this setting. Consequently, survival for 2.0 2.5 months is usually expected ${ }^{4,23}$, similarly to the theoretical example that was described previously. This assumption must be reassessed within the context of therapeutic fasting for morbid obesity, a rather similar situation but where lipid reserves are much more plentiful, and in which total food deprivation for up to one year has been well tolerated ${ }^{6,7,18,20}$.

The population here investigated was not obese, with the possible exception of one subject with a BMI of 30.1 $\mathrm{kg} / \mathrm{m}^{2}$, but their initial BMI was somewhat above the usual range (Table 1).
Therefore, they probably had more energetic tissues to burn than leaner subjects, and anthropometric and BIA determinations tend to confirm this suspicion. In such circumstances, daily fat oxidation should not markedly change, but the end result could be a healthier profile of body composition than previously described for long-term fasting individuals $^{7,14,18}$.

Table 1 reveals that weight loss was precipitous but far from dramatic (approximately $18 \%$ change), and arm muscle circumference, a variable related to muscle mass, was even less affected during the studied period. Triceps skinfold thickness reduced at a higher magnitude, and extrapolation for the total period would suggest a decrease of almost $60 \%$ during the period of food deprivation.

Assuming the figures on Table 5 with regard to total fat oxidation, if $60 \%$ of fat reduction corresponds to approximately $7 \mathrm{~kg}$ of burned fat, then initial body fat should be in the range of 11.7 $\mathrm{kg}$, or $14.5 \%$ of body weight $(80.9 \pm 8.2$ $\mathrm{kg}$ ). Probably actual fat before fasting was appreciably higher, close to $30 \%$ of body weight, as suggested by body weight and triceps skinfold determinations (Table 6). However, proportions of $37 \%$ or $52 \%$, as foreseen by a theoretical equation or bioimpedance analysis, are hardly compatible with other anthropometric and clinical findings. If one accepts the figure of $30 \%$, which seems reasonable, it must be concluded that fat oxidation did not correspond to $60 \%$ of body reserves, because that would amount to more than $14 \mathrm{~kg}$ of consumed fat, or nearly $100 \%$ of real weight loss. According to the reported data, water alone usually represents roughly $50 \%$ of the weight decrease in such circumstances ${ }^{15,21,23}$, which is still less than the $74 \%$ lost by surgical patients. $^{12}$ The more logical hypothesis is that $7 \mathrm{~kg}$ of adipose tissue were lost, representing about $30 \%$ of available stores.
In this study, nitrogen elimination could not be fairly estimated by BIA, which varies directly with fat-free mass (FFM) and varies inversely with body fat. Since anthropometric assessments indicated a greater loss in fat grams than in protein grams, the BIA determinations were influenced most heavily by the fat loss, confounding interpretation with regard to nitrogen elimination. Therefore, the BIA findings suggesting that FFM (and LBM, which is a related variable) increased as fasting advanced must be rejected. Shifts of intracellular water would perhaps furnish more useful indications regarding nitrogen elimination, but this compartment could not be investigated in the present situation. Standard anthropometric assessment in the form of arm muscle circumference is also relatively insensitive for estimating nitrogen elimination because of the possible interference of fluids and bone on the result. In any case, AMC was affected in the proportion of $18 \%$ for the entire fasting period.

If one assumes $13 \mathrm{~kg}$ of total muscle for a healthy young male ${ }^{2}$, the loss should be equivalent to $2.3 \mathrm{~kg}$ of muscle or approximately $20 \%$ of that value in protein $(460 \mathrm{~g})^{2,15,19}$. As demonstrated in Table 5, even the most conservative prediction of protein erosion was above $1 \mathrm{~kg}$, thus suggesting an underestimation of real changes by AMC .

Indirect calorimetry was only performed once in a single patient. Nevertheless, the results fully correspond to the predicted values, thus lending credence to the assumptions of Table 3 . It is interesting to note that the respiratory quotient was under 0.7 , which is theoretically improbable, since 0.7 corresponds to exclusive fat oxidation. Yet such results seem to be entirely typical of prolonged food deprivation and could be explained by fatty acid desaturation ${ }^{18}$.

Few quantitative reports about fluid 
shifts during severe long-term voluntary wasting can be retrieved from the literature. During chronic malnutrition, especially within the context of surgical catabolism, but also in kwashiorkor cases of third-world countries, it is apparent that water accumulates everywhere, especially in the extracellular space $^{8,13,15,23}$. In contrast, initial abundant diuresis is usually observed in obese subjects that engage in total fasting, tapering down after a couple of days, but a relative state of dehydration is maintained $\mathrm{d}^{6,20,23}$. Although fluid balance was not available in this experience, there is indirect evidence that the reported patients followed the obese paradigm, because of the comparatively low readings of total body water, and appropriately elevated determinations of total resistance on the 31st day of hunger strike (Table 2).

The phase of conservation of the remaining water and sodium after the initial depletion is the rule in healthy fasting human beings, but interestingly rats proceed straight to fluid retention when denied food, without any previous negative fluid balance. ${ }^{3}$ The next step, coinciding with refeeding after prolonged starvation, may display some tendency toward peripheral edema, as apparent during the first days or weeks of realimentation of both chronically malnourished and starved obese subjects ${ }^{6,23}$. In the current series, body water restoration with some questionable degree of overshooting was noted immediately upon intensive hydration, as BIA-estimated water rapidly expanded and body resistance diminished in the same proportion (Table 2). Nevertheless, clinical edema was not asignificant problem in any of the patients.

The metabolic profile of the fasting subjects after adaptation that best fits the subjects in this study consists of a total daily energy expenditure of about $1500 \mathrm{kcal} /$ day (roughly $25 \%$ below comparable non-starving subjects, and close to the suggestion of Leiter \& Marliss ${ }^{14}$ ); a probable consumption pattern of at least $90 \%$ lipid calories versus $7 \%-10 \%$ generated by protein $^{18}$; and a total oxidation (43 days) in the range of $60000-70000 \mathrm{kcal}$, divided as fat $(6.0-7.2 \mathrm{~kg})$ and protein + carbohydrate $(1.0-1.8 \mathrm{~kg})$. If one subtracts these numbers from the average total weight loss $(14.5 \mathrm{~kg})$, a balance of $6.0-7.5 \mathrm{~kg}$ of water and electrolytes will appear (rather close to the suggested 50\% ${ }^{15,21,23}$ ).

Based on these premises, a very proper physiologic response was thus elicited in the subjects in this study, with marked reduction of energy expenditure, adequate defense of vital muscle stores, and massive but not prohibitive burning of adipose tissue. Indeed, if total body glycogen is accepted as $600 \mathrm{~g}$ in the adult, ${ }^{2,12,19}$ and total protein + carbohydrate loss was $1.0-1.8 \mathrm{~kg}$, then nitrogen excretion was fairly inconspicuous for the circumstances.

Given the fact that the patients apparently started with sufficient organic reserves at the beginning of the hunger strike, their body composition at the end of 43 days was still nominally more acceptable than what is observed in many hospitalized patients, with a BMI of $21.5 \pm 2.6 \mathrm{~kg} / \mathrm{m}^{2}$.

One is tempted to speculate that the subjects could have fasted considerably longer, similarly to morbidly obese individuals ${ }^{6,20}$. However, this may be a premature impression, since total food deprivation in normal adults is sometimes accompanied by pathophysiologic derangements quite different from what is seen in severe obesity or in chronic partial starvation. It cannot be forgotten that morphologic assessments such as those performed here are comparatively weak prognostic indices regarding morbidity and mortality. ${ }^{16}$ Vital functions may become compromised during rapid weight loss, tissue deproteinization may lead to damage and rupture of myocardial fibres, ${ }^{22}$ and certain crucial micronutrients are more quickly exhausted in some circumstances than in others. Kinney ${ }^{12}$, reviewing previous investigations by Keys et $\mathrm{a}^{11}$ and Benedict ${ }^{1}$, emphasizes the fact that intake of as little as $20 \%$ of the daily calorie requirements may extend the average period before lethality of total fasting from two months or even less to about six months.

Many details of the natural history of human absolute starvation are still obscure, and most were originally documented 50 years ago or earlier. Professional fasting specialists (who fasted in exchange for payment) as used in the beginning of the century by Benedict ${ }^{1}$, cannot be used in modern scientific protocols. Experimental animals do provide many insights, but biological differences with patients certainly exist. Similarly, information accumulated in various modalities of human primary and secondary malnutrition are very useful for understanding fuel consumption and body composition changes during starvation ${ }^{16}$. Nevertheless, actual clinical observations of hunger strikers as here analyzed should be collected whenever available, feasible, and ethical, in order to advance knowledge about this infrequent modality of self-inflicted injury and to provide insights for nutritional assistance and patient care.

\section{CONCLUSIONS}

1) All body compartments diminished with fasting, but adipose tissue was by far the most depleted, thus confirming the overwhelming participation of body lipids in energy balance during uncomplicated prolonged starvation.

2) Measured total water was low and total body resistance comparatively elevated, but these findings rapidly reversed upon rehydration. 
3) Exaggerated fat percentage estimated from BIA tests and simultaneous estimation of increased lean body mass suggested that BIA was inappropriate for estimating energy compartments in the studied population.

4) Anthropometry yielded a body profile more commensurate with clini- cal findings, although some shortcomings concerning muscle mass estimation could be identified as well.

5) According to calculations of both fat and fat-free tissue consumption, patients were not initially malnourished and remained apparently free from high nutritional risk after 43 days of fasting; however, the impact of functional impairments, tissue damage, and micronutrient depletion was not considered in this analysis, and could have severely affected their prognosis if fasting had been prolonged beyond 43 days.
FAINTUCH J e col. - Alterações nos compartimentos hídricos e energéticos do organismo durante a greve de fome. Rev Hosp Clin Fac Med S Paulo 55 (2):47-54, 2000.

A privação total e prolongada de alimentos em adultos não-obesos é raramente vista, e poucos estudos documentaram as modificações da composição corpórea neste contexto.Num grupo de oito casos de greve de fome durante 43 dias, procedeu-se à estimativa dos compartimentos hídricos e energéticos, visando averiguar a influência sobre os mesmos da desnutrição progressiva.Os métodos incluiram índice de massa corporal (IMC), prega cutânea do tríceps (PCT), circunferência muscular do braço, e determinação através da bioimpedância (BIA) da água, massa gorda, massa magra e resistência corpórea total..A calorimetria indireta foi realizada em uma ocasião

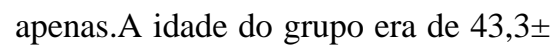
6,2 anos (sete homens, uma mulher), somente água e ocasionais eletrólitos e vitaminas foram ingeridos no jejum, e a perda de peso média foi de $17,9 \%$.

Por volta do $43^{\circ}$ dia da greve iniciou-se a reposição venosa rápida de fluidos, vitaminas e eletrólitos, antes de se prosseguir com a realimentação.A gordura corporal diminuiu em aproximadamente $60 \%$ (BIA e PCT), ao passo que o IMC caiu apenas $18 \%$.A estimativa da gordura total inicial por BIA foi de $52,2 \pm 5,4 \%$ do peso corporal, e mesmo no $43^{\circ}$ dia do evento o valor calculado era de $19,7 \pm 3,8 \%$ do peso.Os valores correspondentes deduzidos da PCT mostraram-se substancialmente inferiores, e mais compatíveis com os demais índices antropométricos.

A água corporal revelou-se inicialmente contraída, com resistência elevada,sendo que estes achados se reverteram rapidamente por ocasião da hidratação venosa rápida.Quando do término da greve de fome o IMC $\left(21,5 \pm 2,6 \mathrm{~kg} / \mathrm{m}^{2}\right)$ e outras variáveis antropométricas revelavam-se numericamente aceitáveis, sugerindo eficien- te conservação de musculatura e energia na fase de dieta zero.Conclui-se que: 1) Todos os compartimentos orgânicos se contrairam na greve de fome, porém o tecido adiposo foi de longe o mais afetado; 2) A água corporal mostrou-se reduzida com elevada resistência total, mas estes achados inverteram-se prontamente mediante hidratação parenteral; 3) $\mathrm{O}$ encontro de gordura total excessiva e de aumento da massa magra com o avançar do jejum sugerem que as leituras de BIA são inapropriadas para esta população e fornecem resultados incoerentes; 4) Com base nos parâmetros expostos os doentes não estavam morfologicamente desnutridos ao cabo de 43 dias, todavia não foram aqui avaliados outros transtornos de considerável importância prognóstica.

DESCRITORES: Greve de fome. Desnutrição aguda. Jejum prolongado. Composição corpórea. Avaliação nutricional. Impedância bioelétrica. 


\section{REFERENCES}

1. BENEDICT FG - A study of prolonged fasting. Washington Publ $1915 ; 203$.

2. BLACKBURN GL, BISTRIAN BR, MAINI BS et al. - Nutritional and metabolic assessment of the hospitalized patient. J Parent Ent Nutr 1977;1:11-22.

3. BOIM MA \& SCHOR N - Renal sodium conservation during starvation in rats. Braz J Med Biol Res 1992; 25:1209-1213.

4. CAHILL Jr GF - Survival in starvation. Am J Clin Nutr 1998; 68:1-2.

5. CUENDET GS, LOTEN EG, CAMERON DP et al. - Hormonesubstrate responses to total fasting in lean and obese mice. Amer J Physiol 1975; 228:276-2831.

6. DRENICK EJ, SWENDSEID ME, BLAHD WH et al. - Prolonged starvation as treatment for severe obesity. J Amer Med Assoc 1964; 187:100-105.

7. DULLOO AG \& JACQUET J - Adaptive reduction in basal metabolic rate in response to food deprivation in humans: a role for feedback signals from fat stores. Am J Clin Nutr 1998; 68:599-606.

8. ELIA M \& LUNN PG - Biological markers of protein-energy malnutrition. Clin Nutr 1997; 16 (Suppl 1):11-17.

9. FRANKENFIELD DC, SMITH JS \& COONEY RN - Accelerated nitrogen loss after trauma is not attenuated by achievement of nitrogen balance. J Parent Ent Nutr 1997; 21:324-329.

10. HEITMANN BL - Evaluation of body fat estimated from body mass index, skinfolds and impedance. A comparative study. Eur J Clin Nutr 1990; 44:831-837.

11. KEYS A, BROZEK J, HENSCHEL A et al. - The biology of human starvation. Minneapolis USA, Univ of Minnesota Press, 1950.

12. KINNEY JM - The tissue composition of surgical weight loss. In: JOHNSTON I. DA (ed) - Advances in parenteral nutrition. Lancaster, MTP Press, 1978. p 511-518.
13. KOTLER DP, TIERNEY AR, WANG I et al. - Magnitude of body cell mass depletion and the timing of death from waisting in AIDS Am J Clin Nutr 1989; 50:444-447.

14. LEITER LA \& MARLISS EB - Survival during fasting may depend on fat as well as protein stores. J Amer Med Assoc 1982; 248:23012307.

15. MOORE FD \& BOYDEN CM - Body cell mass and limits of hydration of the fat-free body. Their relation to estimated skeletal weight. Ann NY Acad Sci 1963; 110:62-71.

16. MORAIS AAC, COMARELLA AO, PITANGA KC et al. - Interest of conventional clinical, biochemical, and bioimpedance measurements as indicators of mortality risk in critical patients. Rev Hosp Clin Fac Med S Paulo 1998; 53:176-180.

17. NEWSOME TW, MASON Jr AD \& PRUITT Jr BA - Weight loss following thermal injury. Ann Surg 1973; 178:215-217.

18. OWEN OE, SMALLEY KJ, D'ALESSIO DA et al. - Protein, fat and carbohydrate anaplerosis and cataplerosis. Am J Clin Nutr 1998; 68:12-34.

19. PASSMORE R \& ROBSON JS. - A companion to medical studies Oxford, UK, Blackwell, 1974. v. 3.

20. RUNCIE J \& MILLER V - Treatment of obesity by total fasting for up to 249 days. Lancet 1966;992-996.

21. SMITH R \& DRENICK EJ - Changes in body water and sodium during prolonged starvation for extreme obesity. Clin Sci 1966 31;437-441.

22. SOURS HE, FRATALLI VP, BRAND CD et al. - Sudden death associated with very low calorie weight reductions regimens. Amer J Clin Nutr 1981; 34:453-46.

23. WEINSIER RL - Fasting-A review with emphasis on the electrolytes. Amer J Med. 1971; 50:233-240.

Received for publication on the: 17/12/99 